\title{
Rapid collaborative knowledge building via Twitter after significant geohazard events
}

\author{
Robin Lacassin ${ }^{1}$, Maud Devès ${ }^{1,2}$, Stephen P. Hicks ${ }^{3}$, Jean-Paul Ampuero ${ }^{4}$, Remy Bossu $^{5,6}$, Lucile Bruhat $^{7}$, Daryono ${ }^{8}$, \\ Desianto F. Wibisono ${ }^{9}$, Laure Fallou ${ }^{5}$, Eric J. Fielding ${ }^{10}$, Alice-Agnes Gabriel ${ }^{11}$, Jamie Gurney ${ }^{12}$, Janine Krippner ${ }^{13}$, \\ Anthony Lomax ${ }^{14}$, Muh. Ma'rufin Sudibyo ${ }^{15}$, Astyka Pamumpuni ${ }^{16}$, Jason R. Patton ${ }^{17}$, Helen Robinson ${ }^{18}$, \\ Mark Tingay ${ }^{19}$, and Sotiris Valkaniotis ${ }^{20}$ \\ ${ }^{1}$ Université de Paris, Institut de physique du globe de Paris, CNRS, 75005 Paris, France \\ ${ }^{2}$ Université de Paris, Institut Humanités Sciences Sociétés, Centre de Recherche \\ Psychanalyse Médecine et Société, CNRS, Paris, France \\ ${ }^{3}$ Department of Earth Science and Engineering, Imperial College London, London, UK \\ ${ }^{4}$ Université Côte d'Azur, IRD, CNRS, Observatoire de la Côte d'Azur, Géoazur, France \\ ${ }^{5}$ European-Mediterranean Seismological Centre, CEA, 91297 Arpajon Cedex, France \\ ${ }^{6}$ CEA Centre DAM Ile de France, 91297 Arpajon, France \\ ${ }^{7}$ Laboratoire de Géologie, UMR 8538, Ecole normale supérieure, PSL University, CNRS, Paris, France \\ ${ }^{8}$ Earthquake and Tsunami Mitigation Division, Indonesian Agency for Meteorology Climatology and Geophysics, \\ Kemayoran, DKI Jakarta 10610, Indonesia \\ ${ }^{9}$ independent researcher: Semarang, Central Java, Indonesia \\ ${ }^{10}$ Jet Propulsion Laboratory, California Institute of Technology, Pasadena, California, USA \\ ${ }^{11}$ Department of Earth and Environmental Sciences, Ludwig-Maximilians-Universität München, Munich, Germany \\ ${ }^{12}$ independent researcher: United Kingdom Earthquake Bulletin, UK \\ ${ }^{13}$ Global Volcanism Program, National Museum of Natural History, Smithsonian Institution, Washington DC, USA \\ ${ }^{14}$ ALomax Scientific, Mouans-Sartoux, France \\ ${ }^{15}$ Local Disaster Management Office (BPBD), Kebumen, Central Java, Indonesia \\ ${ }^{16}$ Institut Teknologi Bandung, Jawa Barat 40132, Indonesia \\ ${ }^{17}$ Department of Geology, Humboldt State University, California, USA \\ ${ }^{18}$ Powerful Earth, UK \\ ${ }^{19}$ Australian School of Petroleum, University of Adelaide, Frome Street 5005, Adelaide, Australia \\ ${ }^{20}$ Koronidos 9, 42131 Trikala, Greece
}

Correspondence: Robin Lacassin (lacassin@ipgp.fr)

Received: 22 October 2019 - Discussion started: 28 October 2019

Revised: 30 March 2020 - Accepted: 1 April 2020 - Published: 15 May 2020

Abstract. Twitter is an established social media platform valued by scholars as an open way to disseminate scientific information and to publicly discuss research results. Scientific discussions on Twitter are viewed by the media, who can then pass on information to the wider public. Social media is used widely by geoscientists, but there is little documentation currently available regarding the benefits or limitations of this for the scientist or the public. Here, we use the example of two 2018 earthquake-related events that were widely commented on by geoscientists on Twitter: the Palu $M_{\mathrm{w}} 7.5$ earthquake and related tsunami in Indonesia and the longduration Mayotte island seismovolcanic crisis in the Indian Ocean. We built our study on a content and contextual analysis of selected Twitter threads about the geophysical characteristics of these events. From the analysis of these two examples, we show that Twitter promotes a very rapid building of knowledge in the minutes to hours and days following an event via an efficient exchange of information and active 
discussion between the scientists themselves and the public. We discuss the advantages and potential pitfalls of this relatively novel way of making scientific information accessible to scholarly peers and lay people. We argue that scientific discussion on Twitter breaks down the traditional "ivory tower" of academia, contributes to the growing trend towards open science, and may help people to understand how science is developed and, in turn, to better understand the risks related to natural/environmental hazards.

\section{Introduction}

In the aftermath of a potentially destructive natural event, such as a powerful earthquake, tsunami, volcanic eruption, or major landslide, it is crucial to rapidly determine its key geophysical and geological characteristics. With such evidencebased understanding, the geoscientific community can credibly explain the phenomenon to the media and stakeholders. Geoscientists can also disseminate the information to people directly affected by the disaster and engage in discussion with them (e.g. Stewart et al., 2018). A rapid understanding is also crucial to evaluate the risk of cascading events (e.g. triggered earthquakes), such as the 2016 earthquakes in central Italy (Chiaraluce et al., 2017; Patton, 2016), and to direct further scientific action. Decades ago, this understanding was achieved at a much slower pace and within closed research teams by a progressive acquisition of geophysical data via time-consuming field surveys. This process often took months to reach a good understanding of the event's characteristics. Thanks to worldwide geophysical instrument networks (e.g. global and regional seismic networks) and satellites (e.g. optical or radar imagery), as well as open data, researchers now generally have enough information to get a satisfactory first-order description of the geophysical event and an estimation of its potential consequences within days (e.g. Hayes et al., 2011). Scholarly interactions via social media, sometimes involving citizen expertise and observations, may transform both the timeliness and the way our geophysical understanding is built and shared (Hicks, 2019; Williams and Krippner, 2019).

Twitter stands as a very efficient and simple tool to publicly disseminate scientific information and rapidly engage in discussion about the cause and implications of geological events (Landwehr et al., 2016; Lee, 2019; Takahashi et al., 2015). While Twitter is not the most popular social media platform, compared with platforms such as Facebook (Fallou and Bossu, 2019; Williams and Krippner, 2019), it is valued by scholars as an interactive and open way to discuss research-related issues and to comment on research results in a concise way (Shiffman, 2017; Van Noorden, 2014). Twitter is also widely used by journalists, who can pass on information to the wider public (Engesser and Humprecht, 2015).

Here we use the examples of the 28 September 2018 $M_{\mathrm{w}} 7.5$ Palu earthquake and the related tsunami in north- west Sulawesi, Indonesia (Bao et al., 2019; Socquet et al., 2019), and the protracted 2018-2019 Mayotte island seismovolcanic crisis in the Indian Ocean (Cesca et al., 2020; Lemoine et al., 2019; Feuillet et al., 2020). We analyse the timelines of Twitter threads from these events to show that a virtual team of scholars sharing complementary data, observations, and analyses, and engaging in subsequent discussions, may lead to a very rapid co-building of knowledge in just 1 to a few days. This process, which crosses laboratory walls (Britton et al., 2019), has the advantage of being transparent to the public and to the media. It makes science accessible to nonacademics or citizen scientists, who can follow and participate in the discussion. Our findings follow growing trends towards open science and also potentially provide the opportunity for a new type of collaborative scientific approach within dynamic and remotely working "global virtual teams" (Zakaria et al., 2004).

\section{Studied events and methodology}

For around a decade now, scientists studying natural hazards have been using information extracted from social media, websites, or app earthquake reporting to automatically detect and locate hazardous events, such as flooding (e.g. Jongman et al., 2015). Social media posts can also be used to locate earthquakes within tens of seconds of their occurrence (Bossu et al., 2008, 2018; Earle et al., 2010; Steed et al., 2019). Here, rather than relying on a quantitative survey based on large-scale keywords or hashtags statistics or utilizing website traffic analysis combined with geolocalization, we built our study on the contextual analysis of qualitative content of selected Twitter conversational threads. We do this to shed light on actual interactions that people have on Twitter during these events, emphasizing the type of information shared via this social media rather than focussing solely on overarching issues. Examples of recent geological events that have received extensive Twitter commentary are the April 2015 Gorkha earthquake in Nepal (see analysis of Twitter response by Lomax et al., 2015), the Mexico earthquakes of September 2017, the Mt. Agung eruption of 2017 (Indonesia), the tsunami induced by volcanic collapse at Anak Krakatau (Indonesia) in December 2018, the July-August 2019 Stromboli eruptions and pyroclastic flows (Italy), the July 2019 Ridgecrest earthquake sequence (California, USA), and the protracted Lusi mud volcano eruption (Indonesia) that started in 2006. We chose to analyse two 2018 events that illustrate complementary aspects of knowledge building via social media.

On 28 September 2018, an magnitude $M_{\mathrm{w}} 7.5$ earthquake occurred in the north-west of Sulawesi island, Indonesia. The earthquake ruptured the Palu-Koro Fault system, a northsouth left-lateral fault zone with a relatively rapid average slip rate of about $4 \mathrm{~cm} \mathrm{yr}^{-1}$ (Socquet et al., 2006), which was previously identified as being a high seismic hazard 
zone (Pusat Studi Gempa Nasional - National Center for Earthquake Studies, 2017; Watkinson and Hall, 2017). This earthquake triggered a tsunami with run-ups reaching 6-8 m high on the Palu Bay coast (Carvajal et al., 2019; Ulrich et al., 2019) as well as widespread liquefaction and surface spreading inland (Valkaniotis et al., 2018; Watkinson and Hall, 2019). To show how key geophysical information was rapidly disseminated and discussed via Twitter, we compiled informative tweets that were posted about the event's characteristics and processes. This list of tweets should not be considered exhaustive, as it is strongly dependent on who we follow on Twitter and what is retweeted. We use it to illustrate how this way of spreading information enhances the dissemination and discussion of scientific results. From this compilation, we built a timeline of the rapid progress of the understanding of the earthquake rupture and of its effects. The timeline (Table A1), which covers the $5 \mathrm{~d}$ following the event, is graphically shown in Fig. 1 (see also Table S1 in the Supplement, which contains web links to selected relevant individual tweets). A Twitter "moment" (Lacassin, 2019) gives online access to the full content of the tweets including images, maps, and videos (a PDF print of the full thread is also available from the Figshare data repository: https://doi.org/10.6084/m9.figshare.11830809.v1). Table S2 provides complementary web links to the Twitter feeds of several geoscientists who actively participated in the online data dissemination and discussion in the few days following the event, giving access to secondary, more detailed discussions.

In contrast to the Palu case, the case of Mayotte, in the Comoros archipelago between East Africa and Madagascar, represented emergent scholarly interaction over a much more protracted time period, without direct damage caused by the unrest and lacking initial responses from official government agencies. The island had been experiencing a long-standing seismic swarm of volcanic-tectonic origin since May 2018 (Patton, 2018; Lemoine et al., 2019; Feuillet et al., 2020), but it was not purported to have any significant seismic or volcanic hazard prior to this crisis. The seismic swarm is still active more than 18 months later and has recently been linked to a migration of magma within the lithosphere and the eruption of an undersea volcano (Cesca et al., 2020; Feuillet et al., 2020). We do not analyse the full (18 months) Twitter activity related to the Mayotte seismic swarm but instead focus on a particular long-period seismic event that happened on 11 November 2018. This event triggered a surge in scholarly Twitter discussions in the following days. The surge resulted in a complex and long (>200 tweets) Twitter thread with many branches opening secondary discussions, more like a wild bush than a well-structured tree. To simplify this thread, our first aim was to select and regroup the most relevant and informative tweets linked to these discussions. We organized these selected tweets into three successive Twitter moments that are accessible online (Lacassin, $2018 \mathrm{a}, \mathrm{b}, \mathrm{c})$, and we invite the reader to consult and re- fer to this long thread (as for Palu, a PDF print of the full thread is also available from the Figshare data repository: https://doi.org/10.6084/m9.figshare.11830824.v1). Our purpose is not to carry out the same timeline analysis as for the Palu earthquake but to use the "Mayotte 11 November 2018 rumble event" example to outline the efficient knowledge-building dialogue between scientists trying to interpret a mysterious event and dealing with the uncertainties surrounding it. To illustrate the time evolution of ideas during this active dialogue, we generated two word clouds from the selected tweets. We also use the Mayotte case to outline the role of citizen scientists at the start of the discussion, to discuss some pitfalls inherent to using an informal platform like Twitter, and to explore the opportunity to spread information toward more traditional print, broadcast, and online media.

The evolution of the two threads was quite different. For Palu, the scenario was quite well defined and occurred at a rapid pace over a short amount of time: an earthquake followed by a tsunami, with the scientists' focus being on the key observations to explain what happened. For Mayotte, we knew very little at first apart from an initially innocuous seismic swarm followed by the detection of a long-period seismic signal. There was no accurate location for the signal and no idea about what the signal was. This resulted in the Twitter exchanges and the overall thread on Mayotte being more chaotic and open than the more linear Palu thread. There were also very different societal impacts. The Mayotte earthquakes caused uncertainty, unrest, and stress, but there was no important damage and no injuries or fatalities. In contrast, devastation and death were immediately seen in Palu.

Most authors of this paper contributed to the Twitter exchanges discussed. Such an "embedded" view has the merit of providing an in-depth understanding of the geophysical observations and of the full context of the online exchanges at the time of the event. To provide an external and more critical view, the paper also includes some authors (MD and LF) who were not involved in these specific Twitter discussions.

\section{Results: knowledge building and sharing via Twitter}

\subsection{The case of the 2018 Palu earthquake}

Our compilation of the Twitter exchanges following the Palu earthquake and tsunami reveals how we can rapidly gain a first-order understanding of event characteristics within a few hours to 1 day and a more complete one in less than a week. After the initial tweets issued by responding agencies (e.g. the USGS in the USA and the BMKG in Indonesia), most of the exchanges we quote involved academic researchers from different countries and institutions (see Tables 1, S1) with specialities encompassing seismology, earthquake geology, tectonic geodesy, remote sensing, natural hazards, and science communication. We will not investigate the sociology 


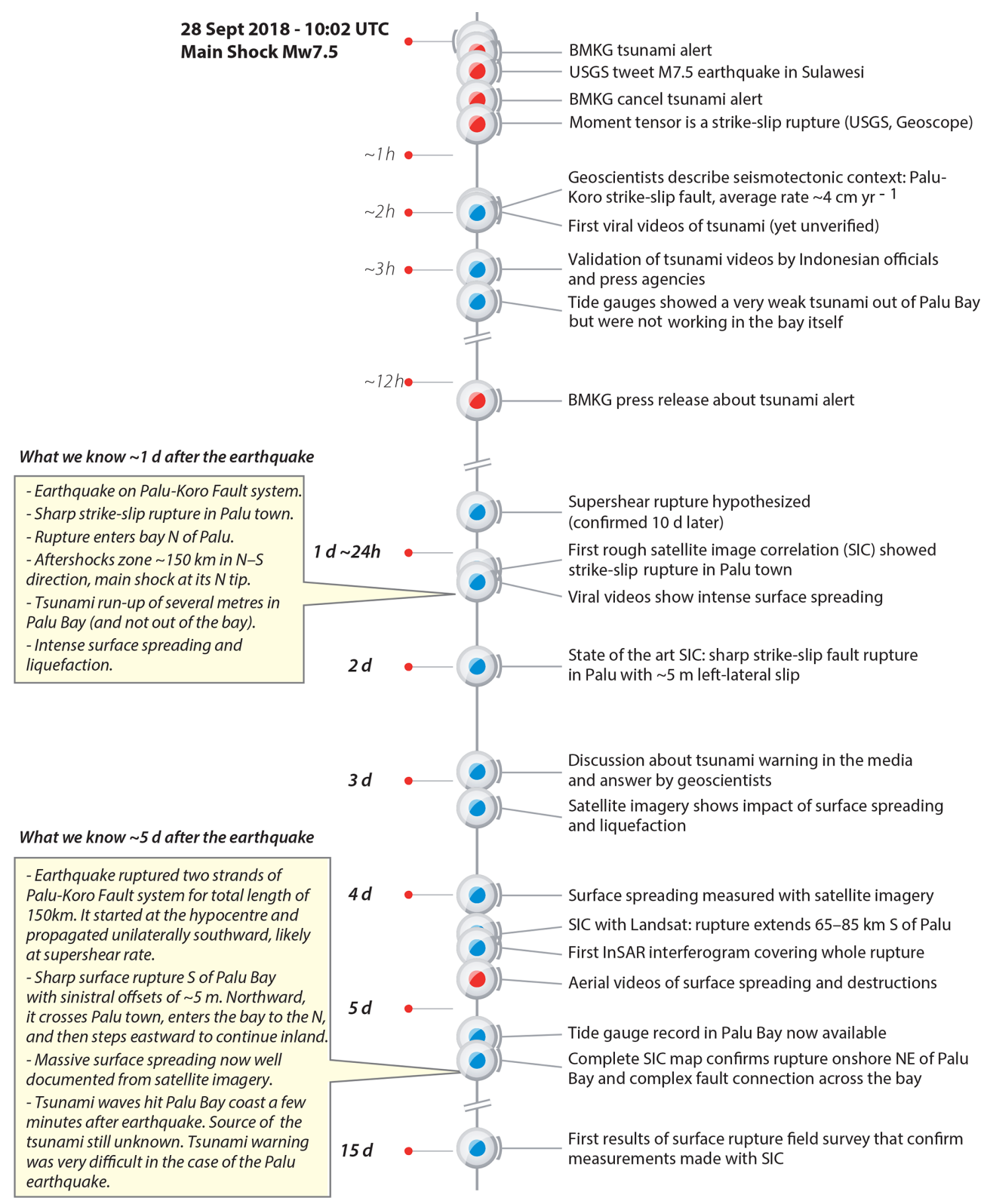

Figure 1. Timeline of information posted on Twitter in the hours and days following the Palu earthquake and tsunami of 28 September 2018. The timeline illustrates the acquisition and dissemination of observations regarding geophysical events and the progress of knowledge building via Twitter. See Table A1 for detailed information on the timing; Table S1 in the Supplement provides links to relevant tweets and Twitter accounts; Figs. 2 and 3 display examples of tweets posted by geoscientists. Red dots correspond to information posted by responding agencies, and blue dots correspond to observations and discussions posted by researchers from different countries and institutions.

of the people involved in the Twitter discussions in more detail, because it is outside the scope of the present study, but future work should address this critical subject.

The timeline built from the Twitter feeds (Figs. 1, 2, Table A1) shows that the geoscience community already knew the following about 1 day after the earthquake:

i. the earthquake happened on the Palu-Koro Fault system, with a sharply localized strike-slip rupture directly beneath Palu City, and the epicentre was located in the
Minahasa Peninsula on the north-east shore of Palu Bay (from earthquake location and moment tensor solutions provided by monitoring agencies, published papers on the seismotectonic context, and regional fault mapping; this information was shared via Twitter in the $2 \mathrm{~h}$ following the event - see Fig. 2a);

ii. the rupture entered Palu Bay, but the geometry of its prolongation offshore toward the Minahasa Peninsula was uncertain (from early post-earthquake satellite im- 

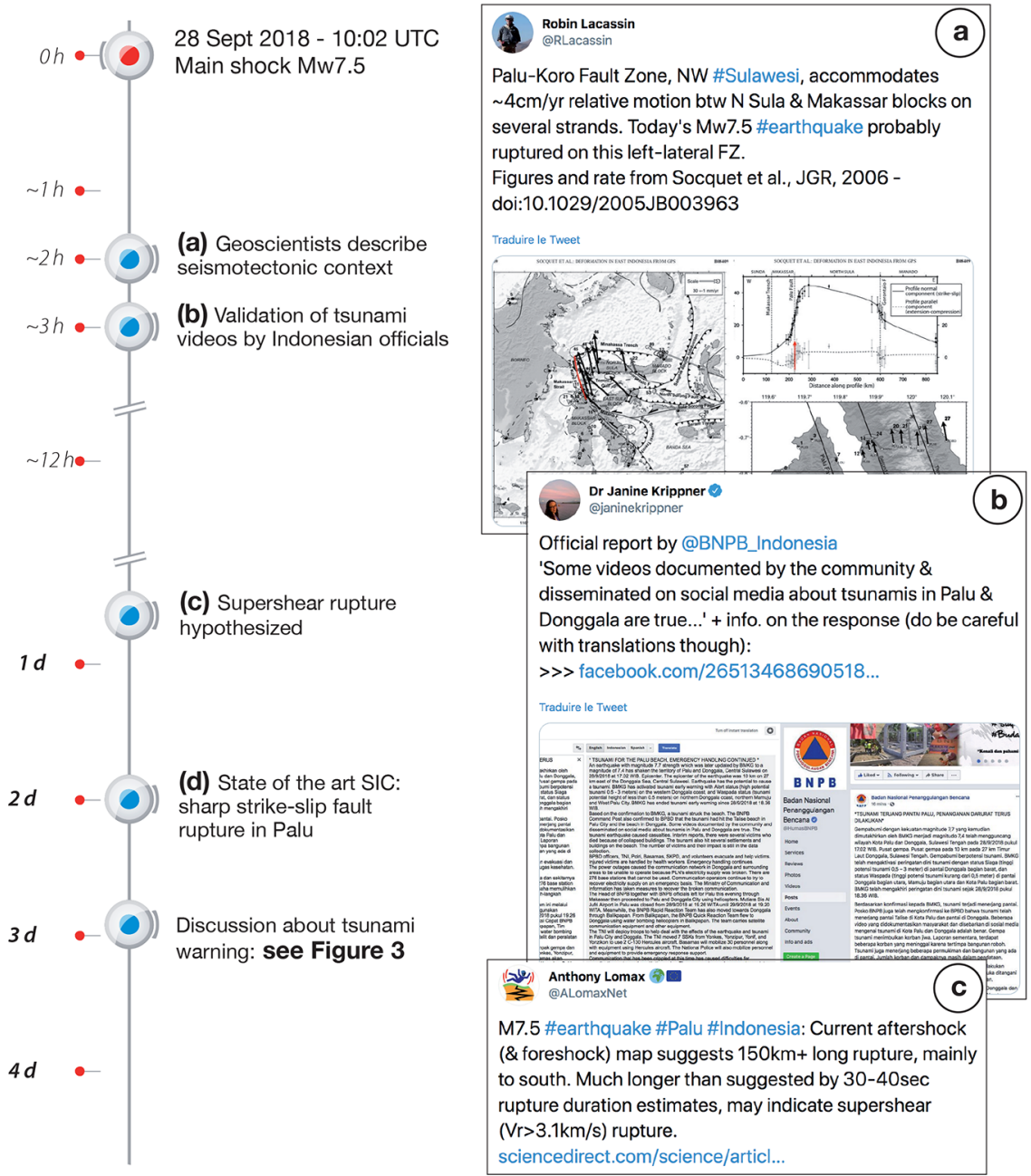

Sotiris Valkaniots

@SotisValkan

Palu fault segment co-seismic rupture through Palo city,

\#Sulawesi, Indonesia, Sep 28 M7.5 \#earthquake.

Displacements of 6-8m on a NNW-SSE east dipping

sinistral fault. Strike-slip ruptures continue south in Palu

valley for kms. Optical correlation w/MicMac \&

@planetlabs imagery.

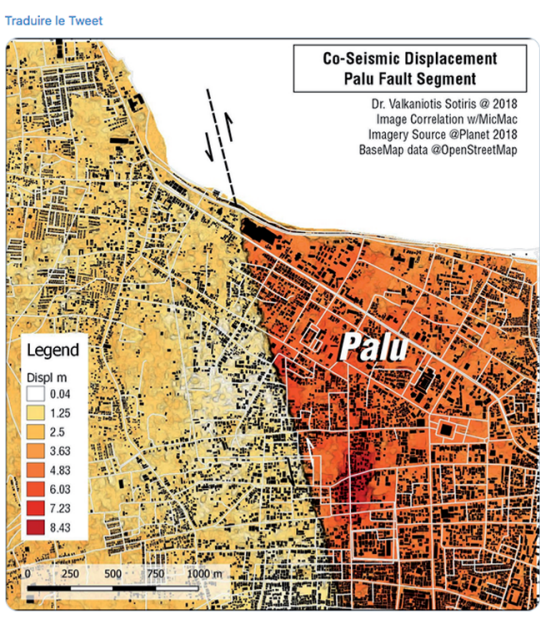

C. Eric Fielding @EricFielding · 30 sept. 2018

En réponse à @SotisValkan et @planetlabs

Wow! That is a very large displacement to have inside a city! This explains

the reports of extreme damage in Palu. \#PrayForPalu

○ $\quad$ 七】 $4 \quad 010$

Anthony Lomax 을 @ALomaxNet · 30 sept. 2018

En réponse à @Sotisvalkan et @planetlabs

$6-8 \mathrm{~m}$ ! Is the mean displacement across the inferred fault this high?

$\begin{array}{lll}01 & \tau \imath & 01\end{array}$

Sotiris Valkaniotis @SotisValkan · 30 sept. 2018

For now we have info for the part near Palu. There should be offshore segments and other parts onshore further north or south. Another site

Q 1 โป 1107

JD Dianala @geoloJD · 30 sept. 2018

8 meters of maximum displacement would cor

Figure 2. Screenshots of tweets chosen to illustrate how researchers shared and explained observations regarding the Palu earthquake and tsunami of 28 September 2018. A simplified timeline (from Fig. 1) is shown on the left for reference. (a) Within $2 \mathrm{~h}$ geoscientists described the seismotectonic context of the earthquake. (b) Geoscientists shared and translated the official validation of viral videos about the tsunami in Palu. (c) Researchers hypothesized supershear rupture. (d) Geoscientists shared satellite image correlation results showing a sharp rupture with a $5 \mathrm{~m}$ left-lateral offset across Palu town, and other researchers started to discuss these results. Refer to Fig. 3 for tweets about the tsunami warning.

agery and preliminary image correlation using pre- and post-event data);

iii. the aftershock zone extended $\sim 150 \mathrm{~km}$ in the northsouth direction, and the mainshock hypocentre was located near the northern tip of this zone (from operational earthquake locations provided by monitoring agencies);

iv. a tsunami with run-ups of several metres hit the shores of Palu Bay but was not recorded out of the bay (from reports and videos shared via social media by local people and the tide gauge records that were available in the hours following the event - see Fig. 2b); v. there was dramatic surface spreading and liquefaction in and south-east of Palu City (from photos and videos shared by locals).

The exchanges and discussions continued via Twitter, and by $5 \mathrm{~d}$ after the earthquake the geoscientific community had assembled a fairly accurate description of the event and its effects. The acquired common and credible knowledge was as follows:

i. the earthquake ruptured two strands of the Palu-Koro Fault system for a total length of $\sim 150 \mathrm{~km}$ (from the aftershock distribution provided by monitoring agencies, radar and optical image analysis results, and early earthquake source models); 
ii. the strand south of Palu Bay had a sharp and extremely localized surface rupture with sinistral offsets of $\sim$ $5 \mathrm{~m}$ (from satellite imagery and state-of-the-art pre-and post-event image correlation, which was later confirmed by field observations posted on Twitter by Indonesian researchers $\sim 15 \mathrm{~d}$ after the event - see Fig. $2 \mathrm{~d}$ );

iii. the rupture started on an inland fault east of Palu Bay and then crossed Palu City from north to south (from satellite and InSAR imagery as well as early earthquake source models);

iv. the earthquake rupture propagated unilaterally southward, likely at a supershear speed (faster than $S$ waves), which was a fairly unique observation for earthquakes (from early earthquake source duration and rupture length estimates, with the latter based first on the distribution of early aftershocks and then on satellite images - see Fig. 2c);

v. massive liquefaction and lateral spreading occurred in several sectors of Palu City (from aerial video footage shared by local government agencies, satellite imagery, and photos and videos shared by locals on social media);

vi. tsunami waves hit the Palu Bay coast only a few minutes after the earthquake (from tide gauge records and videos shared on social media).

Ensuing Twitter exchanges during the next weeks focussed on the surface rupture description in the field by Indonesian scientists, the bathymetry of Palu Bay, the possible fault geometry across it, and hypotheses about the tsunami source. These hypotheses explored whether the tsunami was due to the seismic rupture itself, due to underwater landslides and coastal collapse, or due to a combination of the two.

In this process of common knowledge building, geoscientists used a diverse range of data types that were openly shared and discussed on Twitter: published papers and maps about the seismotectonic context, teleseismic data, local seismic waveforms, high-resolution optical satellite images, synthetic aperture radar (SAR) satellite data analysis, tide gauge records, and field observations from both science groups and local residents. Data sharing and social interaction via Twitter appeared to be an effective way of getting prompt and diverse feedback from fellow researchers on early scientific ideas. The satellite image correlation results, available on Twitter 1-2 d after the earthquake, were then rapidly shared as a more formal report via the open repository zenodo.org (Valkaniotis et al., 2018). Some ideas and initial hypotheses about a supershear rupture and the offshore fault geometry in Palu Bay, both discussed on Twitter, provided impetus for accelerated development of in-depth scientific papers (Bao et al., 2019; Ulrich et al., 2019). Indonesian geoscientists, absent from the earlier scholarly exchanges on Twitter (only official agencies were providing advice), progressively joined the discussion, providing, for example, tide gauge records and field observations of fault surface rupture and offsets. This created the opportunity to develop new international collaborations. Further highlighting the use of social media, an analysis of the tsunami source by Carvajal et al. (2019) used videos posted on social media platforms such as Twitter and YouTube.

The spread of information via Twitter was not restricted to a small group of geoscience scholars. Journalists used and quoted these Twitter discussions in their articles (e.g. Andrews, 2018a; Wei-Haas, 2018a), using the thread to identify academic experts to interview for their articles. However, some journalists were not interested in the full range of geophysical observations and focussed instead on a "failed tsunami alert" (Fountain, 2018; Wright, 2018). Based on an Associated Press (AP) dispatch, on 1 October 2018, quoting some scientists (Wright, 2018), there were inaccurate reports from international media outlets about a "failed" tsunami warning. According to these reports, a network of tide gauges and buoys would have been able to issue an early tsunami warning after the earthquake, thereby saving lives. The media were quick to blame the Indonesian authorities, saying that such a warning would have been impossible because the Indonesian buoy network was not well maintained. However, geoscientists realized that there was not enough time to issue any warning given the very short distance between the earthquake source and the areas exposed to the tsunami in the very narrow Palu Bay (Fig. 3). As stated by Carjaval et al. (2019), "the most remarkable features of the tsunamis that devastated Palu were the very short, nearly instantaneous arrival times". The first tsunami waves indeed hit the coast between 1 and 2 min after the earthquake. After the evidence-based explanation given by scholars on Twitter (Fig. 3), the process of fact-checking by some journalists took only a few hours after the publication of the AP dispatch (e.g. Morin, 2018).

As described above, the case of the Palu earthquake and tsunami provides an excellent example of how scholarly discussions on Twitter can provide initial and rapid scientific results, whilst also reinforcing local official authorities on the ground and helping to guide journalistic outputs.

\subsection{The Mayotte 11 November 2018 rumble event}

On 11 November 2018, more than 6 months after the start of an earthquake swarm between Madagascar and the Comoros archipelago in the Indian Ocean, a peculiar seismic signal radiated from the region of Mayotte. The signal was recorded worldwide by seismic networks, but it was not detected by their automatic event identification algorithms because of its odd spectral characteristics. It was an unusually long, lowfrequency, highly monochromatic signal, like a low-pitched hum that travelled as seismic waves across the Earth.

As noted by journalist Maya Wei Haas in her National Geographic article "only one person noticed the odd signal on the U.S. Geological Survey's real-time seismogram displays. 


Steven J. Gibbons
When a huge earthquake takes place and we see it was a
so-called strike-slip earthquake, we usually assume that
a destructive tsunami will not add to the woes. This
week's quake showed us again that nature is often more
complicated than we'd like. nytimes.com/2018/09
/30/wor...
En réponse à @ALomaxNet @stevenjgibbons et @BaptisteGomb
Given the size of the bay north of Palu and distance to the
epicenter, a very robust and high quality sensor perhaps
every 10 km would be needed for a warning system that
could have helped - about 5000 to 10000 such sensors
to cover Indonesia...
en.wikipedia.org/wiki/List_of_c...

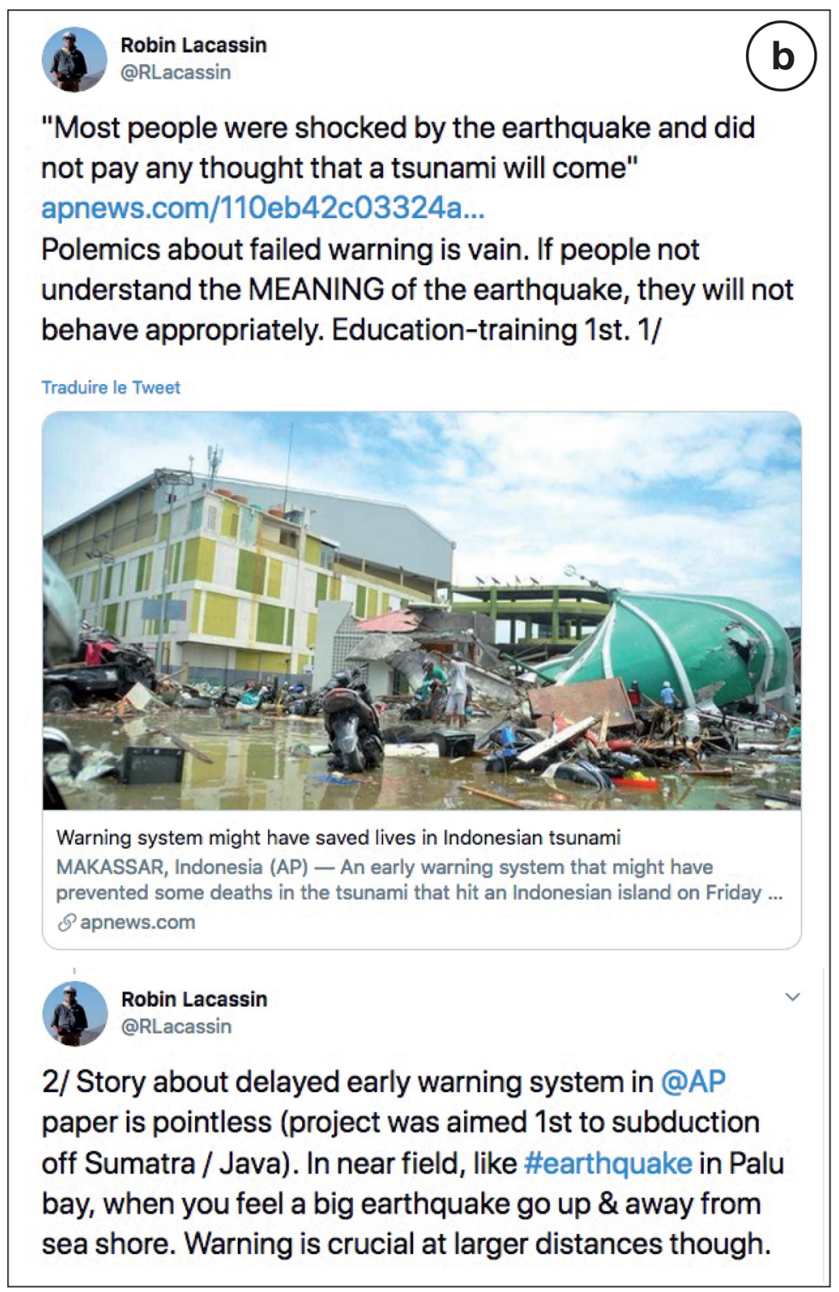

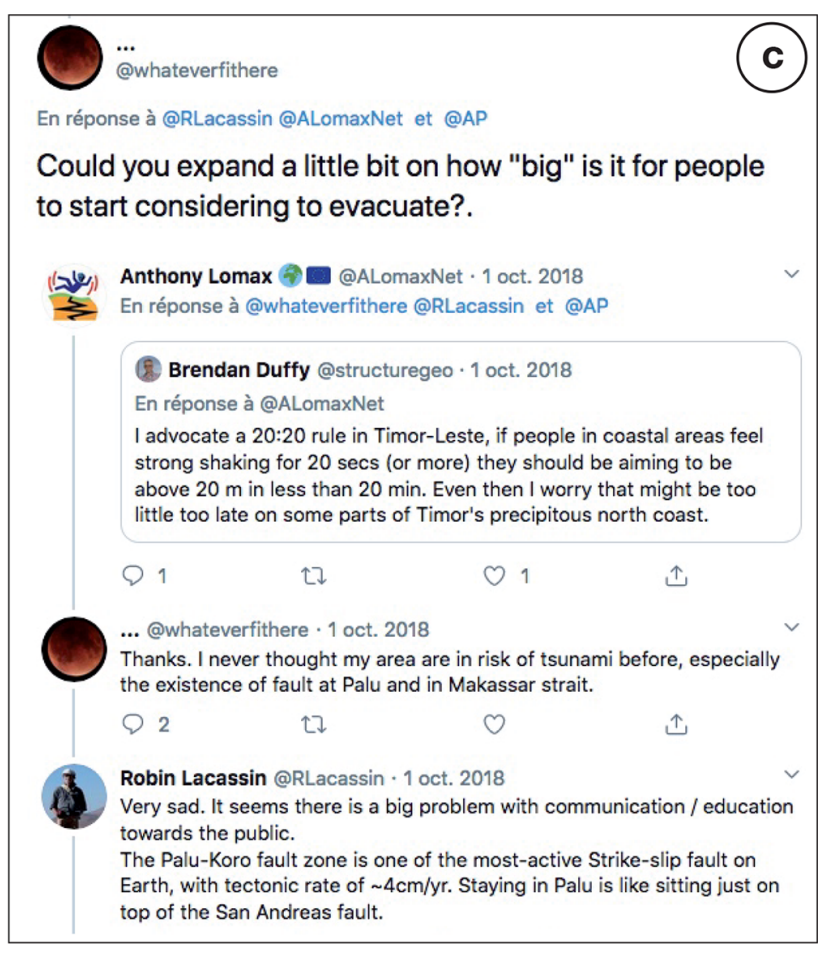

Dr Janine Krippner

@janinekrippner

I have seen people slamming the Indonesian agencies for lifting the tsunami warning before it hit Palu. This timeline shows that this was not the case.

Tsunami warning lifted at 17:36 WIB, after the tsunami.

Via@infoBMKG @BNPB_Indonesia

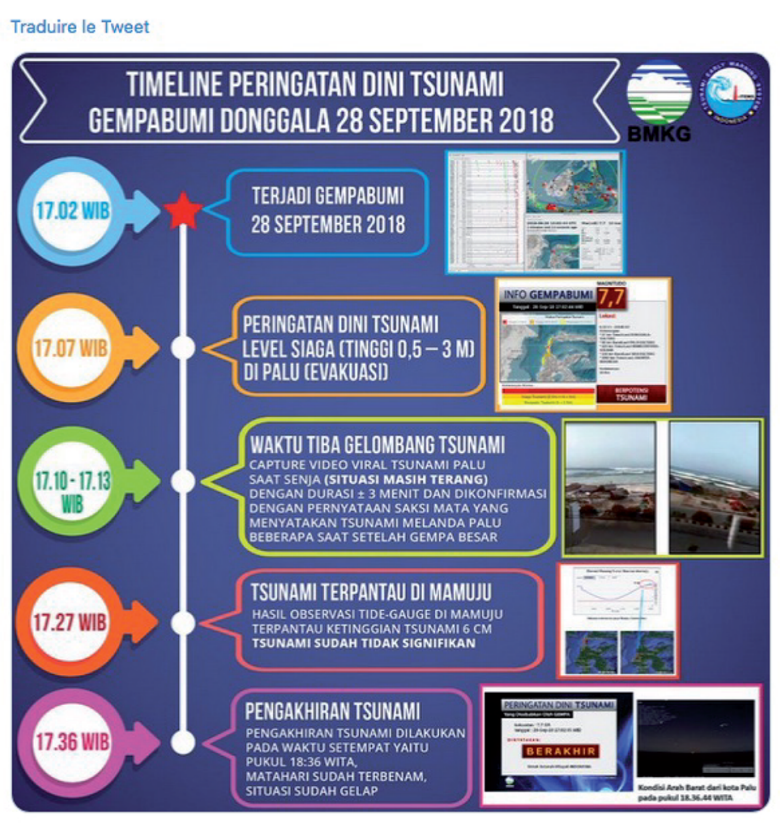

Figure 3. Screenshots of selected tweets about the tsunami warning in the case of Palu. (a, b) Geoscientists quote media articles regarding a possible "failed" tsunami warning and explain that such a warning was extremely difficult in the case of the Palu earthquake (see text for more details). (c) An example of geoscientists engaging in discussion with local people. (d) A geoscientist reports that Indonesian agencies issued an alert in due time and cancelled it only after the tsunami hit Palu. 
An earthquake enthusiast [...] saw the curious zigzags and posted images of them to Twitter" (Wei-Haas, 2018b). This image (Fig. 4a) was then retweeted by a citizen earthquake researcher, Jamie Gurney, who initiated an active discussion between academic researchers (Fig. 4), with some interactions from the media and the public. Analysis of openly accessible seismic waveform data from around the world by seismologists then confirmed the signal originated in the Mayotte region (e.g. Hicks, 2018a).

The Twitter discussion involved a group of seismologists but also specialists in earthquake geology, volcanology, tectonics, geodesy, geomechanics, hazards, and science communication. Their exchanges eventually co-built a rapid appraisal of the 11 November signal and of its broader geophysical and geological context. The nature of the researchers' interactions are exemplified by the three successive Twitter moments (Lacassin, 2018a, b, c) that regroup our compilation of tweets (see Fig. 4 for a choice of tweets illustrating the early discussion between researchers). A simple content analysis of the selected tweet threads, illustrated by the two successive word clouds in Fig. 5, shows how the exchanges started with questions about the odd seismic signal itself (using words such as signal, event(s), wave(s), seismic, and frequency) and its geographic origin (using words such as Mayotte and location) (Fig. 5a) and then moved to a discussion more focussed on the event's geophysical source (using words such as source, signal, CMT, CLVD, and deformation) and data processing (using words such as data, model, InSAR, and inversion) (Fig. 5b). While many things remain to be understood about the geophysical processes at work offshore of Mayotte, the preliminary waveform modelling shared via Twitter (Hicks, 2018b) and the related discussion resulted in the consensus hypothesis that the 11 November seismic signal was due to a deflation event in a large and deep magmatic chamber combined with resonance and amplification of the seismic waves. This early hypothesis discussed on Twitter was subsequently supported by later in-depth analyses (Lemoine et al., 2019; Cesca et al., 2020; Feuillet et al., 2020).

The Twitter interactions on Mayotte drew the attention of the global geoscience community. Before the 11 November event, the long-standing earthquake swarm near Mayotte had been largely ignored; the swarm had only been studied by only a few researchers, mainly French, because Mayotte is a French territory. As noted by Lemoine et al. (2019), the 11 November event "awakened the interest of the seismological community and the media". We understand that the rapid "explosion" of the informal Twitter discussions that we report played a pivotal role in this awakening and helped hasten needed research in the region (Hicks, 2019). A few days after the 11 November event, at a meeting between the French geoscience community and stakeholders (funding agencies and ministry representatives), the Twitter exchanges were used to demonstrate the urgency with respect to funding research and surveys on the Mayotte earthquake swarm (Nathalie Feuillet, personal communication to RL, 2018).

The full interactive process on Twitter was the subject of two long articles in National Geographic (Wei-Haas, 2018b) and Gizmodo (Andrews, 2018b), with journalists gathering information and contacting researchers via Twitter before interviewing them via email or phone (Fig. 6). These articles were then used as primary sources by other media and stimulated stand-alone reports by more traditional news organizations (e.g. Sample, 2018).

The long thread about the Mayotte 11 November seismic event reveals the efficiency of knowledge building via scholarly online interactions, but it also outlines some pitfalls that are inherent in the informal aspect of exchanges via Twitter. While after the Palu earthquake and tsunami geoscientists were posting solid observations (i.e. "knowns"), for Mayotte they were trying to understand a peculiar event with large uncertainties, thereby opening many secondary discussions about "unknowns". The resulting "bushy" nature of the thread makes it difficult to follow and comprehend in real time, and summarizing it a posteriori is challenging. Moreover, some of these secondary discussions were casual or humorous and were at risk of being seen as insensitive and taken out of context by the general public. We infer that scientific Twitter exchanges dealing with uncertainties and unknowns, as for Mayotte, are more prone to such pitfalls than those sharing knowns.

\section{Discussion: advantages and pitfalls of Twitter for knowledge exchange and co-building}

\subsection{Argument 1: very rapid co-building of knowledge}

The two case studies described above support previous work showing that Twitter allows the rapid building of knowledge (e.g. Choo et al., 2015; Hicks, 2019). In the case of the 2018 $M_{\mathrm{w}} 7.5$ Palu earthquake, it took only $5 \mathrm{~d}$ to obtain a detailed description of the events and only a few days for the 11 November 2018 seismovolcanic event in Mayotte. It takes several months to years for scientific teams to gather relevant information, analyse it, and publish it in an academic journal after a long review-revision process. Thus, using Twitter makes information and basic explanations accessible to the scientific community and to the public more quickly. Communicating such ideas to the public may have a high impact in places where operational infrastructure and associated communication are limited. Moreover, Twitter provides direct and early scientific information for researchers, without any geographical and institutional barriers, acting as a "science news feed" that can be used to plan further in-depth research.

However, the knowledge built via Twitter is not exactly comparable to the knowledge built by a longer-term, classical academic approach. Even if a long practice of research allows scientists to estimate the quality of a data set or of a 
2. $* * * * * *$ Pax @matarikipax. 11 nov. 2018

This is a most odd and unusual seismic signal.

Recorded at Kilima Mbogo, Kenya ...

\#earthquake

earthquake.usgs.gov/static/earthqu...

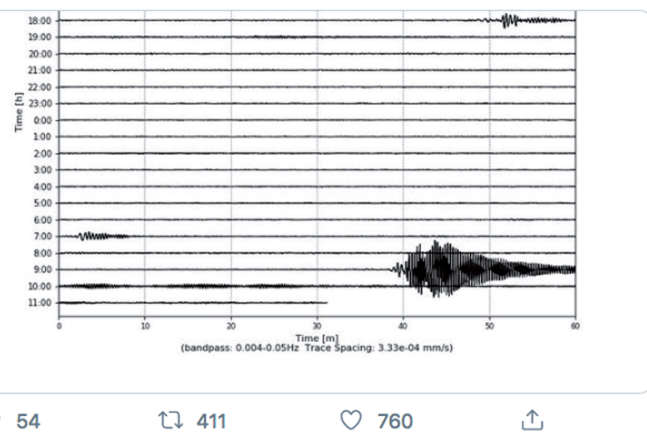

Jamie Gurney @UKEQ Bulletin · 11 nov. 2018

This is the recording of the 09:30 UTC Southern Indian Ocean event from Kilima Mbogo, Kenya. The signal has had a highpass filter applied to it at $0.01 \mathrm{~Hz}, 0.05 \mathrm{~Hz}, 0.1 \mathrm{~Hz} \& 0.2 \mathrm{~Hz}$ respectively. As can be seen the signal is very low frequency @stevenjgibbons @ALomaxNet
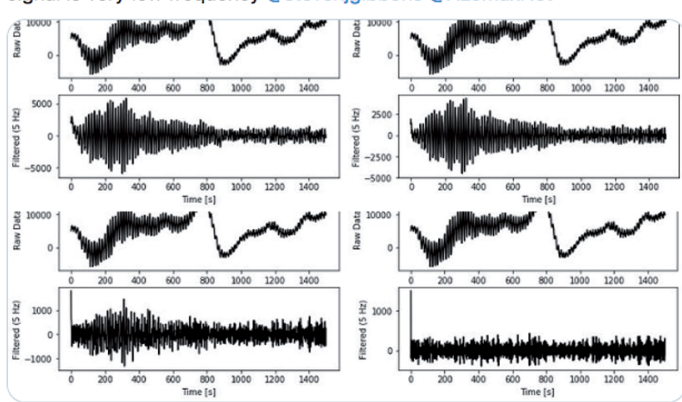

(b)

Q 14

$\uparrow\urcorner 129$

○ 225

个

Jamie Gurney @UKEQBulletin · 11 nov. 2018

Confirmation of location places it near the Comoros. Arrival times from FOMA (Southern Madagascar) \& KMBO (Kenya) are almost identical, with FOMA perhaps slightly closer ( $<1$ minute prior arrival time) - sadly I cannot narrow down the arrival time any better for FOMA.

(c)

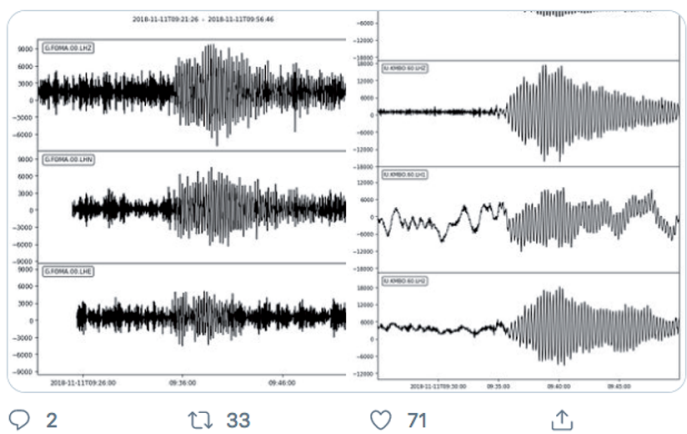

Anthony Lomax 90 @ALomaxNet · 11 nov. 2018

En réponse à @ALomaxNet et @UKEQ_Bulletin

SBV like the other stations, shows long monochromatic signal with $\sim 17 \mathrm{~s}$ period (mono-freq Rayleigh waves?). But filtered above $1 \mathrm{~Hz}$ SBV (lower plot) also shows seismic(?) signals from repeating sources, with some $\sim 50$ s apart. Maybe some large, shallow, oscillating volcanic source?

(d)

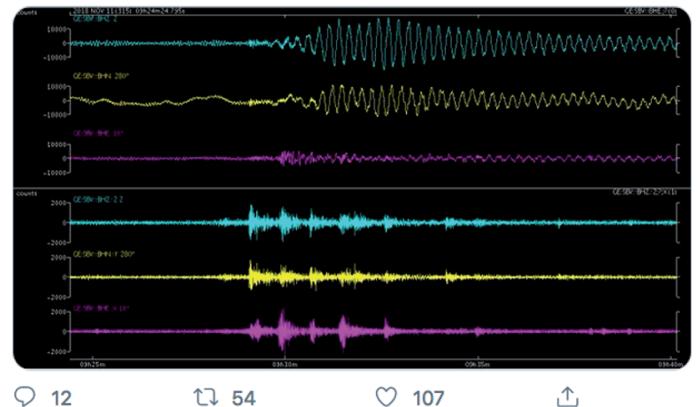

Jamie Gurney @UKEQ_Bulletin·11 nov. 2018

En réponse à @TTremblingEarth @stevenjgibbons et 3 autres We are now of the opinion it was a massive phreatic eruption near Mayotte, possibly related to the earthquake sequence which has been ongoing since May. @ALomaxNet mentioned that the signal seems to have $\sim 17 \mathrm{~s}$ wavelength, so it is very low frequency.

Stephen Hicks? @seismo_steve 12 nov. 2018

En réponse à @seismo_steve @ALomaxNet et 4 autres

So I wondered if GCMT has detected this event since it has lots of energy at long periods.

And what do you know, here it is! It's given a magnitude of 5.0, which presumably is $\mathrm{Mw}$ or Ms. Ideo.columbia.edu/ ekstrom/Resea...

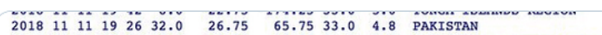

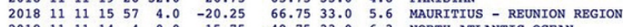

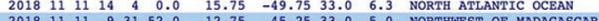
$\begin{array}{lllllllllll}2018 & 11 & 11 & 8 & 26 & 48.0 & 31.50 & 141.50 & 33.0 & 4.7 & \text { SOUTHEAST OF HONSHU, JAPAN }\end{array}$ $\begin{array}{llllllllllll}2018 & 11 & 11 & 7 & 13 & 44.0 & 1.75 & 127.25 & 33.0 & 5.2 & \text { HALMAHERA, INDONESIA } \\ 2018 & 1 & 12 & 6 & 47 & 4.0 & -10.75 & 56.25 & 3330 & 5.2\end{array}$

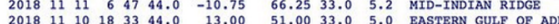

Stephen Hicks @seismo_steve · 12 nov. 2018

En réponse à @seismo_steve @ALomaxNet et 4 autres

As far as I can see right now, that event is not in any other seismic

g catalogue - probably because shorter-period body wave energy was really weak, so it was missed by conventional detection systems.

Baptiste Gombert @BaptisteGomb·12 nov. 2018

En réponse à @edwardpeguero1 @RLacassin et @BRGM_fr

Likely something volcanic, but what exactly is hard to say due to the lack

(h) of data in the proximity. As @seismo_steve and @UKEQ_Bulletin

suggested, it could be the slow collapse of a magmatic chamber

Helen Robinson @Geology_Helen·13 nov. 2018

En réponse à @matarikipax @seismo_steve et 11 autres

They are very bizarre looking signals. A chamber roof collape wouldn't produce such an evenly distributed "pulse" signal. Rock fracturing might I guess, depending on the processes causing the fracturing

Stephen Hicks @ @seismo_steve · 13 nov. 2018

En réponse à @matarikipax @Geology_Helen et 11 autres It could be that high-frequency and low-frequency sources are accompanied and occurring simultaneously. A slow collapse event, might still be accompanied by more tectonic-looking events related to smallerscale fracturing/faulting around the volcanic system.

Figure 4. Screenshots illustrating early Twitter exchanges about the very long-period seismic signal near Mayotte on 11 November 2018. The selected screenshots show that Twitter discussion was initiated by citizen scientists (a-c) and then progressively involved academic researchers $(\mathbf{d}-\mathbf{f})$. Those researchers then started an active discussion about the seismic signal and its possible origin $(\mathbf{e}-\mathbf{j})$.

methodology almost immediately (if not intuitively), it does not substitute peer review as a process to check the validity of a result and "establish" knowledge. Therefore, a question arises regarding the credibility and legitimacy of the knowledge built rapidly and without peer review via Twitter: can it be believed and on what ground? The fact that the author of a tweet comes from a recognized expert institution increases his/her credibility. Nevertheless, this is not enough to ensure the scientific quality of his/her tweet - and the reverse is also true. As shown in the Mayotte example, nonpractising re- 

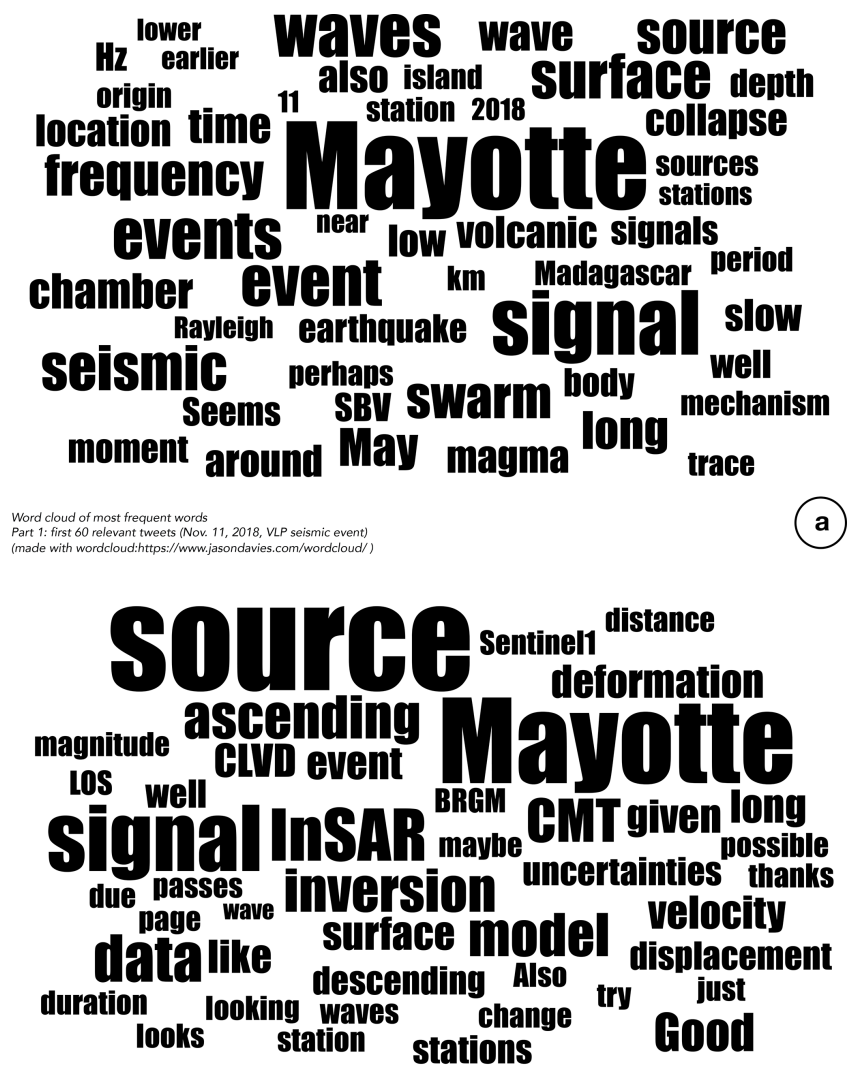

Word cloud of most frequent words
Part 2: following b0 relevant tweets (Nov. 11, 2018, VLP seismic event)
(made with wordcloud:https://www.jasondavies.com/worddloud/)

Figure 5. Word clouds illustrating the evolution of topics discussed on Twitter after the Mayotte 11 November 2018 very long-period (VLP) seismic event. The top word cloud (a) illustrates the first 60 tweets of the selected Twitter moment with most frequent words regarding the VLP signal (signal, event(s), wave(s), seismic, and frequency) and its geographic origin (Mayotte and location). The bottom word cloud (b), which corresponds to the subsequent 60 tweets, shows a discussion more focussed on the geophysical source of the VLP event (source, signal, CMT, CLVD, and deformation) and data processing (data, model, InSAR, and inversion).

searchers and "hobby scientists" can develop a good scientific understanding and can legitimately discuss these topics (Fig. 4). Thus, the following question arises: how can we ensure that the most qualified comments receive the most attention?

Rapid dissemination of early scientific analysis products (for example, using up-to-date remote sensing data) to scientists working in the field is another aspect of using social media platforms. This use of social media is similar to the modern trends of using preprint servers for early sharing of scientific results. Twitter interaction is now also forming the basis of collaborations, leading to the development of ideas and the subsequent co-writing of papers within diverse, multidisciplinary teams, e.g. Hicks et al. (2019) and Ulrich et al. (2019) included co-authorships that were instigated from
Twitter discussions. By widening stakeholder interactions, such open discussions may also help to enhance the scholarly value of open data sets.

A risk to sharing "breaking science" information on Twitter and social media is that this same information can enable publications by the global community before the local scientists who provided the initial information. There are vulnerabilities for those field teams who are committing resources as part of a response initiative and are required to, or feel a duty to, provide timely public information about an event. Elements of such a scenario unfolded following the 2016 Kaikōura earthquake in New Zealand, when tweets, blog posts, and media releases by the responding agencies were an important information source for an early publication by researchers without collaboration with the responding agency scientists. This publication (Shi et al., 2017) predated publications of field observations and analysis by teams on the ground by several months. This example raises questions about the ownership of scientific knowledge that is shared in the public domain and suggests that some scientists may choose to completely restrict, or be more selective about, publicly posting their scientific analysis into the public domain.

\subsection{Argument 2: science beyond the laboratory}

Twitter allows us to step outside the laboratory in many ways. First, it opens the door to professional networking and new academic collaborations between scientists from different disciplines, institutions, or even countries. In the case of the Palu earthquake, most of the early exchanges involved non-Indonesian academic researchers; Indonesian geoscientists then joined the discussion and provided data that could only be acquired locally (e.g. field observations about the earthquake rupture or liquefaction-induced landslides). This led them to engage in a discussion with other members of the international scientific community and paved the way for new collaborations, such as the sharing of tsunami source models for operational hazard analyses. In the short term, however, it might be difficult for local scientists to get involved in social media if they are busy with the management of the crisis and/or collecting the first information from the field. Furthermore, scientists from local monitoring organizations or universities may have strict social media usage and communication policies.

Twitter also opens the door to exchanges with the global public. The scientific value of contributions from nonacademics varies between examples, but there are always some external inputs that help to clarify or reframe the scientific questions and the way to explain them to the public. Nonacademics can launch important discussions. In the case of Mayotte, it was a citizen scientist who drew attention to a strange seismic signal (Fig. 4a), and it was the subsequent "explosion" of informal Twitter discussions that woke the scientists and the authorities up (Lemoine et al., 2019; Hicks, 2019). 
Dr. Maya Wei-Haas

@WeiPoints

The morning of November 11, strange seismic waves rippled around the world. Nobody felt them-and no one knows why.

I dig into this fascinating geologic mystery in my latest for @NatGeo!

Traduire le Tweet

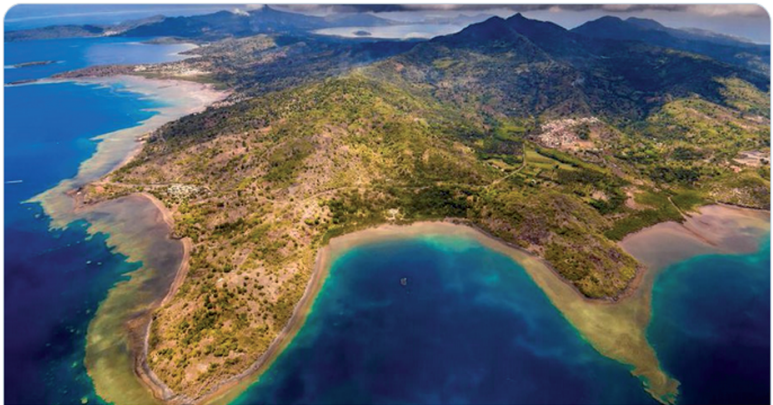

Strange waves rippled around the world, and nobody knows why

Instruments picked up the seismic waves more than 10,000 miles away-but

bizarrely, nobody felt them.

a

S nationalgeographic.com

4:27 PM · 28 nov. 2018 - Twitter Web Client

Dr. Maya Wei-Haas @WeiPoints· 28 nov. 2018

En réponse à @WeiPoints

Much thanks to the many scientists who patiently answered my abundant (and sometimes repetitive) questions about the strange signals! @seismo_steve @Geology_Helen @DocTerremoto @L_Fallou @ALomaxNet

(b) @RLacassin

Dr. Maya Wei-Haas @WeiPoints · 28 nov. 2018

Oh! And of course, @matarikipax for some fascinating conversation about these signals and more :)
Dr Robin George Andrews

@SquigglyVolcano

IT'S HERE! This story has it all: mysterious seismic signals with no concrete explanation, some of the loveliest scientists I've spoken with, a parable, a reference to Jocelyn Bell Burnell, and jokes (yes, jokes) about sea monsters. My latest for @Gizmodo

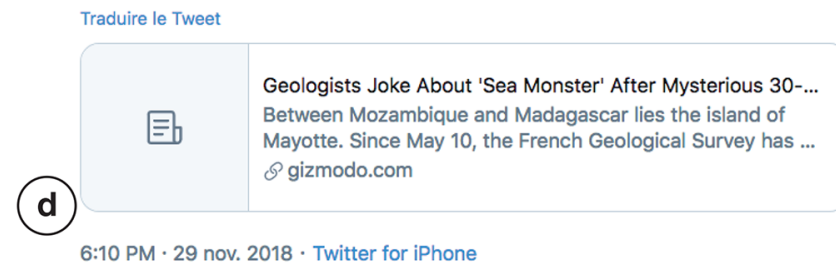

6.10 PM 29 nov. 2018 - Twitter for iPhon

Dr Robin George Andrews 而 @SquigglyVolcano · 29 nov. 2018 En réponse à @SquigglyVolcano

Thanks a million to @seismo steve, @DocTerremoto, @RLacassin, @Geology_Helen and @ALomaxNet for spending time chatting with me about it, and for @CriticalStress_for the coelacanth references. Also, high-five to @WeiPoints for obvious reasons. :)

Figure 6. Screenshots of tweets by journalists Maya Wei-Haas and Robin George Andrews. After promoting their media article on the Mayotte 11 November 2018 event (a, d), the journalists acknowledged academic researchers who were first identified and contacted via Twitter and then interviewed via email or phone $(\mathbf{b}, \mathbf{c}, \mathbf{e})$.

Among Twitter users, journalists "listening in" are particularly important as they can pass on some of the scientific content of the discussions in an understandable way. The challenge for them is to have access to information that is as fresh as it is credible. From this point of view, Twitter is an important resource because it can serve as a pool of potential experts to give in-depth comment (Fig. 6). Conversely, perhaps this trend reduces the diversity in these pools, with public comment favouring scientists on Twitter rather than those who avoid Twitter and/or use other social media platforms. Moreover, how much checking does a journalist do to assess a tweeter's scientific credibility?

\subsection{Argument 3: opening the scientific process to the public}

The process of knowledge building on Twitter is open and public, which may help to improve the general public's and the media's understanding of how scientific research works. The examples described above show that the process of knowledge co-construction is not linear. Some discussion threads might look like well-structured "trees" (e.g. the Palu earthquake) but others resemble "wild bushes" with many secondary branches of discussions opening up over time (e.g. the Mayotte seismovolcanic crisis). Scientists are seen by the public to use a wide variety of data and following indirect, unchronological, and unstructured thought paths before reaching a conclusion. As a window to the scientific process, Twitter also helps to clarify that scientific work is organized into disciplines and subdisciplines and that the knowl- 
edge and know-how of these groups may be difficult to articulate, but they are all necessary to build a global view of a subject. Scientists themselves are familiar with these aspects of their work but non-scientists may not be, largely because scientific knowledge is often presented retrospectively as having been constructed in a cumulative and chronological manner. Epistemologists have long denounced this misconception (e.g. Kuhn, 1996). Thus, Twitter can contribute to making the "messy part of science" more tangible and visible. Early information on Twitter can also provide excellent teachable material for educators.

One limitation is that the thread has to be "visible" on Twitter, using a proper hashtag for instance. Also, if the public is not aware of the sphere and the discussion is not "visible" to them, they will not see it even though it is public. Moreover, some schools of thought, especially those from a public safety standpoint, may argue that scientists should concentrate on disseminating the certainty of known, wellestablished facts and interpretation about a hazardous event, rather than on communicating uncertainties and cutting-edge research (e.g. Jones, 2020). It is our view that scientists must reach a careful balance between knowledge building and being sensitive to a damaging geohazard event very soon after it has happened.

\subsection{Argument 4: helping people to understand hazards and risk mitigation}

Improving people's understanding of natural phenomena can help to improve risk mitigation, at least indirectly. For example, in the case of the Palu earthquake, the international media insisted that a "failed" tsunami warning was responsible for the associated fatalities, but scientists quickly realized and explained that there was not enough time to issue an efficient alert because of the proximity of the earthquake (see above). In fact, the Indonesian agency in charge (BMKG) issued an alert a few minutes after the event and then cancelled it $\sim 30$ min later (Fig. 3d, Table A1); in the meantime, the tsunami hit the Palu Bay coasts (Krippner, 2018). Later the same day, BMKG issued a press release to explain their alert management process. This contradictory information is likely to open a debate that will improve the general public's understanding of what to expect (or not) from early-warning systems. More generally, by bringing facts and evidencebased arguments into the public debate, the scientific community can contribute to the quality of people's information and, in the long-term, help people to prepare. Twitter discussions are opportunities to prevent confusion and misunderstanding by reinforcing and disseminating information and advice given by local government agencies (Bartel and Bohon, 2019).

\section{Concluding remarks}

Using examples of Twitter discussions following two very different geophysical events, we have shown that open scientific discussion and hypothesis building on social media can promote and enhance many key aspects of modern science, including the development of ideas for future project funding, early dissemination and discussion of preliminary results forming the basis of peer-reviewed publications, networking for developing international collaborations, demonstrating the impact of research, and public dissemination of research and results. Twitter can be seen as a modern method of crowdsourcing scientific ideas; however, this can raise moral issues over the proper acknowledgement of how these ideas were progressively developed. In these concluding remarks, we combine the results from the present study with our own experience on social media to identify some interesting questions and implications for modern scientific methods and communication.

Our analysis has shown that Twitter discussions do not represent a significant change over the common methods adopted in traditional scientific research. For example, scientific discussions on Twitter may be compared to traditional in-lab scholar discussions at coffee time and encounters at scientific conferences that are a usual way of exchanging information and new ideas. Twitter democratizes such scholarly interactions by expanding their interdisciplinarity and geographic coverage, leading to more diverse scientific inputs. Many of these differences result from an increase in open data, a willingness to openly share ideas, and the globalization of science. Moreover, in the examples described in this paper, the group of scientists involved in the discussions had not previously worked together. They formed a group with a diverse range of backgrounds and with different expertise, questioning previous tweets, thereby providing an effective and rapid analogue to traditional peer review.

Nevertheless, there are key differences compared with the traditional scientific method that we should be wary of. Whilst we have demonstrated that the use of Twitter for scientific knowledge building and dissemination can be a fulfilling experience, the immediate tangible benefits for scientists that may be needed for, e.g. career progression, may not be obvious. For example, research managers less accustomed to science on social media may find such efforts to be a distraction from traditional research work. The current academic system rewards scientists mostly based on peerreviewed publications, so how can scientists be rewarded for such public dissemination and preliminary groundwork? Also, what happens if research papers are published that use the scientific ideas developed on Twitter without appropriate credit? How can credit be given to the incremental development of scientific ideas from Twitter?

Based on our experience, as science on Twitter is conducted fully in the public domain, we should be wary of comments being taken out of context and the potential of 
posts to "go viral". As a Twitter user gains followers, their responsibility and the risk of such issues dramatically increases, and as the number of comments/replies from followers grow, so does the time required to reply responsibly. In such cases, should this public-facing approach be left to social media and public relations experts? Alternatively, should media and communication training become a standard for scientists working in fields with public-facing aspects?

Aside from occasional conspiracy theorists and charlatan earthquake/volcanic eruption predictors, we have found from our experience of Twitter that communicating about natural geohazards can be less affected than other topics by the wellrecognized disadvantages of the platform - such as trolling and personal abuse. However, challenges still remain for the scientific discussion and dissemination of more controversial subjects, such as human-induced seismicity, petroleum science, or climate change. Does exposing the "messy part of science" (see above) help to increase public trust in scientific evidence? For example, it might be possible for some people to clearly see the uncertainty in some scientific arguments and to "prey" on them for political gain. Overall, opening up the scientific processes and involving the general public as stakeholders should help to improve trust in experts. Future development of "best" practices for scientists involved in such subjects will be needed. However, offering communication training is only one step toward supporting scientists in the effective conveyance of their work. Current issues like climate change show us that scientists need to be openly communicating and building trusting relationships with global communities, but, at the same time, the response from a minor group of other scientists can be hostile and damaging. We need to specifically acknowledge and reward scientists for these crucial efforts and keep working to change the culture to support science communicators.
Together with the growing popularity of open science and preprint archives, discussing science on Twitter can importantly fill in the traditional "radio silence" from science between a newsworthy/impactful event and the publication of related scientific papers that follows months to years later. Our study has specifically focussed on potentially hazardous geological events, but our experiences reported here can assist the usage of social media for many other fields of research. 


\section{Appendix A}

Table A1. Timetable of main events and preliminary geophysical information posted on Twitter about the Palu earthquake and tsunami of 28 September 2018 (Table S1 provides links to the relevant tweets).

\begin{tabular}{|c|c|c|c|}
\hline Important event, information, or result & $\begin{array}{l}\text { Tweeted by (@nnn } \\
\text { refers to the Twitter account) }\end{array}$ & $\begin{array}{r}\text { Time posted } \\
(\mathrm{hh}: \mathrm{mm} \text { UTC })\end{array}$ & $\begin{array}{r}\text { Day posted } \\
\text { (UTC) }\end{array}$ \\
\hline Foreshock $M_{\mathrm{W}} 6.1$ (USGS location and time) & & 07:00 & 28 Sep 2018 \\
\hline Main shock $M_{\mathrm{W}} 7.5$ (USGS location and time) & & $10: 02$ & 28 Sep 2018 \\
\hline BMKG first tsunami alert & @infoBMKG & 10:07 & 28 Sep 2018 \\
\hline BMKG tweet mainshock & @infoBMKG & 10:09 & 28 Sep 2018 \\
\hline Preliminary first motion mechanism: strike-slip & @ ALomaxNet & $10: 16$ & 28 Sep 2018 \\
\hline USGS tweet mainshock & @USGSBigQuakes & $10: 20$ & 28 Sep 2018 \\
\hline BMKG cancel tsunami alert & @infoBMKG & $10: 36$ & 28 Sep 2018 \\
\hline Strike-slip moment tensor & e.g.@geoscope_IPGP & $10: 47$ & 28 Sep 2018 \\
\hline $\begin{array}{l}\text { Seismotectonic context: strike-slip rupture on Palu- } \\
\text { Koro Fault, a major fault system with a } \sim 4 \mathrm{~cm} \mathrm{yr}^{-1} \\
\text { long-term rate (comparable to the San Andreas Fault) }\end{array}$ & Several & $12: 00$ & 28 Sep 2018 \\
\hline $\begin{array}{l}\text { First viral videos of tsunami in Palu } \\
\text { (unverified and not validated at this time) }\end{array}$ & Several & $12: 00$ & 28 Sep 2018 \\
\hline $\begin{array}{l}\text { Confirmation of the tsunami and the official validation } \\
\text { of viral videos }\end{array}$ & $\begin{array}{l}\text { e.g. @ AP quoting Indonesian agency; } \\
\text { @janinekrippner; @Sutopo_PN }\end{array}$ & 13:00 & 28 Sep 2018 \\
\hline Seimotectonic map showing past seismicity & @CPPGeophysics & $15: 20$ & 28 Sep 2018 \\
\hline $\begin{array}{l}\text { Tide gauges: very weak signal out of Palu Bay - not } \\
\text { working at Pantaloan in the bay itself }\end{array}$ & e.g. @RLacassin & $15: 37$ & 28 Sep 2018 \\
\hline $\begin{array}{l}\text { BMKG press release about tsunami alert and why they } \\
\text { ended it }\end{array}$ & @infoBMKG & $00: 40$ & 29 Sep 2018 \\
\hline $\begin{array}{l}\text { Synthetic poster of seismotectonic context and seismic- } \\
\text { ity }\end{array}$ & @patton_cascadia & 01:07 & 29 Sep 2018 \\
\hline $\begin{array}{l}\text { Supershear rupture hypothesized (will be confirmed } \\
\text { later) }\end{array}$ & @ALomaxNet; @DocTerremoto & & \\
\hline Planet Labs imagery suggests rupture right in Palu town & @SotisValkan & $13: 40$ & 29 Sep 2018 \\
\hline $\begin{array}{l}\text { First rough Planet Labs satellite image correlation (SIC) } \\
\text { reveals fault rupture in Palu (results will go viral) }\end{array}$ & @SotisValkan & $14: 04$ & 29 Sep 2018 \\
\hline $\begin{array}{l}\text { Videos of dramatic surface spreading/liquefaction (will } \\
\text { become viral) as will the ensuing discussion }\end{array}$ & $\begin{array}{l}\text { e.g. @ @ janinekrippner; } \\
\text { ton_cascadia }\end{array}$ & $15: 33$ & 29 Sep 2018 \\
\hline
\end{tabular}

About $1 \mathrm{~d}$ after earthquake, we already know the following:

Earthquake on the Palu-Koro Fault system with sharply localized strike-slip rupture in Palu town itself; the rupture enters the bay north of Palu (but it is uncertain how it prolongates offshore and northward); the aftershock zone extends for $\sim 150 \mathrm{~km}$ in the north-south direction, and the mainshock is near its northern tip.

Tsunami with run-up of several metres in Palu Bay

(not out of the bay) with dramatic surface spreading and liquefaction in and south-east of Palu town

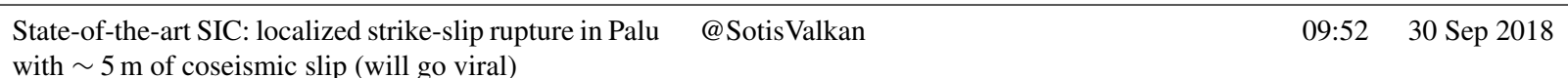


Table A1. Continued.

\begin{tabular}{|c|c|c|c|}
\hline $\begin{array}{l}\text { Updated SIC map of rupture in Palu and displacement } \\
\text { profile }\end{array}$ & @SotisValkan & $16: 10$ & 30 Sep 2018 \\
\hline $\begin{array}{l}\text { Discussion in the international media and social net- } \\
\text { works about a "failed" tsunami warning }\end{array}$ & Several & 06:00 & 1 Oct 2018 \\
\hline $\begin{array}{l}\text { Geoscientists explain that a tsunami warning was very } \\
\text { difficult in the case of the Palu earthquake }\end{array}$ & Several & 09:00 & 1 Oct 2018 \\
\hline $\begin{array}{l}\text { Satellite imagery: surface spreading/liquefaction (con- } \\
\text { firmed by video footage) and the tsunami impact }\end{array}$ & e.g. @ davepetley; @StefLhermite & $12: 24$ & 1 Oct 2018 \\
\hline $\begin{array}{l}\text { Map of coseismic displacement now for } 20 \mathrm{~km} \text { south of } \\
\text { Palu (from Planet Labs SIC) }\end{array}$ & @ SotisValkan & $17: 44$ & 1 Oct 2018 \\
\hline Surface spreading measured with SIC & $@$ SotisValkan & 10:09 & 2 Oct 2018 \\
\hline $\begin{array}{l}\text { Wider SIC map from Sentinel-2 imagery: rupture ex- } \\
\text { tends }>50 \mathrm{~km} \text { south of Palu }\end{array}$ & @SotisValkan & $16: 45$ & 2 Oct 2018 \\
\hline $\begin{array}{l}\text { SIC with Landsat images: confirms sharp rupture ex- } \\
\text { tending } 65-85 \mathrm{~km} \text { south of Palu }\end{array}$ & @TTremblingEarth & $18: 11$ & 2 Oct 2018 \\
\hline $\begin{array}{l}\text { First InSAR interferogram (from ALOS-2 satellite) } \\
\text { covering whole rupture }\end{array}$ & @planet_mech & $19: 21$ & 2 Oct 2018 \\
\hline $\begin{array}{l}\text { Aerial video footage of massive surface spreading and } \\
\text { destruction south-east of Palu }\end{array}$ & @Sutopo_PN & $21: 16$ & 2 Oct 2018 \\
\hline $\begin{array}{l}\text { Tide gauge record in Pantaloan now available; } \\
\text { tsunami's first arrival was only a few minutes after } \\
\text { earthquake }-\sim 2 \mathrm{~m} \text { height }\end{array}$ & $\begin{array}{l}\text { @ marufins; @ALomaxNet; @RLa- } \\
\text { cassin }\end{array}$ & $12: 45$ & 3 Oct 2018 \\
\hline $\begin{array}{l}\text { Complete SIC map (Sentinel-2 imagery): rupture step- } \\
\text { ping onshore east of Palu Bay; implies complex connec- } \\
\text { tion across the bay; epicentre at the northern tip of the } \\
\text { rupture. }\end{array}$ & @SotisValkan & $15: 57$ & 3 Oct 2018 \\
\hline $\begin{array}{l}\text { Validated InSAR interferogram and along-track dis- } \\
\text { placement map, covering whole rupture (from ALOS-2 } \\
\text { satellite) }\end{array}$ & @GSI_chiriin & 09:53 & 5 Oct 2018 \\
\hline Known and unknown $8 \mathrm{~d}$ after earthquake: & \multicolumn{3}{|c|}{$\begin{array}{l}\text { The earthquake ruptured two strands of the Palu-Koro Fault system } \\
\text { for a total length of } \sim 150 \mathrm{~km} \text { : one strand south of Palu bay, } \\
\text { with extremely sharp localized surface rupture and sinistral } \\
\text { offsets of } \sim 5 \mathrm{~m} \text {. It crosses Palu town and enters the bay to } \\
\text { the north. However, the rupture does not continue straight } \\
\text { northward - it steps eastward to continue inland. } \\
\text { Earthquake rupture started to the north at the hypocentre and } \\
\text { propagated southward, likely at a supershear rate. Massive } \\
\text { surface spreading is documented from satellite imagery. } \\
\text { Tsunami waves hit Palu Bay coast few minutes after the } \\
\text { earthquake. Polemics about a "failed" tsunami warning is in vain. }\end{array}$} \\
\hline $\begin{array}{l}\text { First results of surface rupture field survey by Indone- } \\
\text { sian geologists }\end{array}$ & @ pamumpuni & $20: 42$ & 13 Oct 2018 \\
\hline
\end{tabular}


Data availability. PDF prints of the full threads of selected tweets are available from the Figshare data repository for the Palu earthquake and tsunami (https://doi.org/10.6084/m9.figshare.11830809.v1, Supplement 1) and for the Mayotte VLP seismic event (https://doi.org/10.6084/m9.figshare.11830824.v1, Supplement 2).

Supplement. Table S1 lists the main geophysical events and information shared via Twitter after the Palu event, with links to relevant tweets. Table S2 provides web links to the Twitter feeds of geoscientists who participated in the online data dissemination and discussion after the Palu event. The supplement related to this article is available online at: https://doi.org/10.5194/gc-3-129-2020supplement.

Author contributions. This paper follows exchanges on Twitter after the Palu and/or Mayotte events in which most of the authors participated. JG and DFW, as citizen scientists, alerted the scientific community to the Mayotte 11 November event and translated Indonesian geohazard information in English respectively. RL conceived the study and compiled and analysed the data. All authors commented on the results. RL, MD, and SPH wrote the paper with input from all co-authors.

Competing interests. The authors declare that they have no conflict of interest.

Acknowledgements. This paper is a collaborative study following Twitter discussions between co-authors. It is dedicated to the late Sutopo Purwo Nugroho, former chief spokesperson of the Indonesia disaster mitigation agency (BNPB), for his open communication toward the public, in particular via Twitter. Robin Lacassin's position is funded by CNRS (Centre National de la Recherche Scientifique, France). Part of this research was performed at the Jet Propulsion Laboratory, California Institute of Technology under contract with the National Aeronautics and Space Administration. We thank Christopher Jackson and Beth Bartel for their detailed and helpful reviews. This study contributes to the IdEx Université de Paris ANR-18-IDEX-0001. This is IPGP contribution no. 4140.

Review statement. This paper was edited by Mathew StillerReeve and reviewed by Christopher Jackson and Beth Bartel.

\section{References}

Andrews, R. G.: Indonesian Tsunami: What Happened, How To Survive One, And How To Help, Forbes, 1 October, available at: https://www.forbes.com/sites/robinandrews/ (last access: 5 July 2019), 2018a.

Andrews, R. G.: Geologists Joke About "Sea Monster" After Mysterious 30-Minute Rumble Emanates from Waters Near Madagascar, Gizmodo, available at: https://gizmodo.com/ (last access: 5 July 2019), 2018b.
Bao, H., Ampuero, J.-P., Meng, L., Fielding, E. J., Liang, C., Milliner, C. W. D., Feng, T., and Huang, H.: Early and persistent supershear rupture of the 2018 magnitude 7.5 Palu earthquake, Nat. Geosci., 12, 200-205, https://doi.org/10.1038/s41561-0180297-z, 2019.

Bartel, B. and Bohon, W.: The Hazards of Hazard Communication: Importance, Rewards, and Challenges of Science in the Public Sphere: A white paper summary of presentations from session PA23B at the 2018 Fall Meeting of the 485 American Geophysical Union, available at: https://www.iris.edu/hq/files/ (last access: 8 May 2020), 2019.

Bossu, R., Mazet-Roux, G., Douet, V., Rives, S., Marin, S., and Aupetit, M.: Internet Users as Seismic Sensors for Improved Earthquake Response, Eos, Transactions American Geophysical Union, 89, 225-226, https://doi.org/10.1029/2008eo250001, 2008.

Bossu, R., Roussel, F., Fallou, L., Landès, M., Steed, R., Mazet-Roux, G., Dupont, A., Frobert, L., and Petersen, L.: LastQuake: From rapid information to global seismic risk reduction, Int. J. Disast. Risk Re., 28, 32-42, https://doi.org/10.1016/j.ijdrr.2018.02.024, 2018.

Britton, B., Jackson, C., and Wade, J.: The reward and risk of social media for academics, Nat. Rev. Chem., 3, 459-461, https://doi.org/10.1038/s41570-019-0121-3, 2019.

Carvajal, M., Araya-Cornejo, C., Sepúlveda, I., Melnick, D., and Haase, J. S.: Nearly Instantaneous Tsunamis Following the $M_{\mathrm{W}} 7.52018$ Palu Earthquake, Geophys. Res. Lett., 46, 51175126, https://doi.org/10.1029/2019GL082578, 2019.

Cesca, S., Letort, J., Razafindrakoto, H. N. T., Heimann, S., Rivalta, E., Isken, M. P., Nikkhoo, M., Passarelli, L., Petersen, G. M., Cotton, F., and Dahm, T.: Drainage of a deep magma reservoir near Mayotte inferred from seismicity and deformation, Nat. Geosci., 13, 87-93, https://doi.org/10.1038/s41561-019-0505-5, 2020.

Chiaraluce, L., Di Stefano, R., Tinti, E., Scognamiglio, L., Michele, M., Casarotti, E., Cattaneo, M., De Gori, P., Chiarabba, C., Monachesi, G., Lombardi, A., Valoroso, L., Latorre, D., and Marzorati, S.: The 2016 Central Italy Seismic Sequence: A First Look at the Mainshocks, Aftershocks, and Source Models, Seismol. Res. Lett., 88, 757-771, https://doi.org/10.1785/0220160221, 2017.

Choo, E. K., Ranney, M. L., Chan, T. M., Trueger, N. S., Walsh, A. E., Tegtmeyer, K., McNamara, S. O., Choi, R. Y., and Carroll, C. L.: Twitter as a tool for communication and knowledge exchange in academic medicine: A guide for skeptics and novices, Med. Teachnol., 37, 411-416, https://doi.org/10.3109/0142159X.2014.993371, 2015.

Earle, P., Guy, M., Buckmaster, R., Ostrum, C., Horvath, S., and Vaughan, A.: OMG Earthquake! Can Twitter Improve Earthquake Response?, Seismol. Res. Lett., 81, 246-251, https://doi.org/10.1785/gssrl.81.2.246, 2010.

Engesser, S. and Humprecht, E.: Frequency or Skillfulness: How professional news media use Twitter in five Western countries, Journalism Stud., 16, 513-529, https://doi.org/10.1080/1461670X.2014.939849, 2015.

Fallou, L. and Bossu, R.: Taking into account the cultural context to improve scientific communication - Lessons learned from earthquakes in Mayotte, EGU Seismology, available at: 
https://blogs.egu.eu/divisions/ (last access: 30 August 2019), 2019.

Feuillet, N., Jorry, S. J., Crawford, W., Deplus, C., Thinon, I., Jacques, E., Saurel, J. M., Lemoine, A., Paquet, F., Daniel, R., Gaillot, A., Satriano, C., Peltier, A., Aiken, C., Foix, O., Kowalski, P., Laurent, A., Beauducel, F., Grandin, R., Ballu, V., Bernard, P., Donval, J. P., Geli, L., Gomez, J., Guyader, V., Pelleau, P., Rinnert, E., Besançon, S., Bertil, D., Lemarchand, A., and Van der Woerd, J.: Birth of a large volcano offshore Mayotte through lithosphere-scale rifting, Nature, in revision, 2020.

Fountain, H.: Indonesia Tsunami's Power After Earthquake Surprises Scientists, New York Times, 30 September, available at: https://www.nytimes.com/2018/09/30/world/asia/ indonesia-tsunami-science.html (last access: 5 September 2019), 2018.

Hayes, G. P., Earle, P. S., Benz, H. M., Wald, D. J., Briggs, R. W., and the USGS/NEIC Earthquake Response Team: 88 Hours: The U.S. Geological Survey National Earthquake Information Center Response to the 11 March 2011 $M_{\mathrm{W}}$ 9.0 Tohoku Earthquake, Seismol. Res. Lett., 82, 481-493, https://doi.org/10.1785/gssrl.82.4.481, 2011.

Hicks, S.: Tweet - Low-frequency seismic rumblings originated close to the island of Mayotte, Twitter, available at: https:// twitter.com/seismo_steve/status/1062042619264581633 (last access: 1 October 2019), 2018a.

Hicks, S.: Tweet about preliminary CMT inversion, Twitter, available at: https://twitter.com/seismo_steve/status/ 1065976362253647874 (last access: 15 July 2019), 2018b.

Hicks, S.: Geoscience analysis on Twitter, Nat. Geosci., 12, 585586, https://doi.org/10.1038/s41561-019-0425-4, 2019.

Hicks, S. P., Verdon, J., Baptie, B., Luckett, R., Mildon, Z. K., and Gernon, T.: A Shallow Earthquake Swarm Close to Hydrocarbon Activities: Discriminating between Natural and Induced Causes for the 2018-2019 Surrey, United Kingdom, Earthquake Sequence, Seismol. Res. Lett., 90, 2095-2110, https://doi.org/10.1785/0220190125, 2019.

Jones, L. M.: Empowering the public with earthquake science, Nat. Rev. Earth Environ., 1, 2-3, https://doi.org/10.1038/s43017-0190007-4, 2020

Jongman, B., Wagemaker, J., Romero, B. R., and De Perez, E. C.: Early Flood Detection for Rapid Humanitarian Response: Harnessing Near Real-Time Satellite and Twitter Signals, ISPRS Int. J. Geo-Inform., 4, 2246-2266, https://doi.org/10.3390/ijgi4042246, 2015.

Krippner, J.: Timeline of BMKG tsunami warning, Twitter, available at: https://twitter.com/janinekrippner/status/ 1046728583627108354 (last access: 9 October 2019), 2018.

Kuhn, T. S.: The Structure of Scientific Revolutions, 3rd Edn. (1st Edn. published in 1962), University of Chicago Press, 1996-212, 1996.

Lacassin, R.: Mayotte earthquake swarm, discussion 2018 mid November, Twitter, available at: https://twitter.com/i/moments/ 1062037784909832192 (last access: 4 July 2019), 2018 a.

Lacassin, R.: 2/n Mayotte earthquake swarm, 2nd part of discussion - 2018 mid Nov, Twitter, available at: https://twitter.com/ i/moments/1064977870529925121 (last access: 4 July 2019), 2018b.
Lacassin, R.: 3/n Mayotte earthquake swarm, 3rd part of discussion, Twitter, available at: https://twitter.com/i/moments/ 1067410879233368065 (last access: 4 July 2019), 2018 c.

Lacassin, R.: Palu earthquake - Co-building knowledge timeline, Twitter, available at: https://twitter.com/i/moments/ 1073575303979692032 (last access: 3 July 2019), 2019.

Landwehr, P. M., Wei, W., Kowalchuck, M., and Carley, K. M.: Using tweets to support disaster planning, warning and response, Saf. Sci., 90, 33-47, https://doi.org/10.1016/j.ssci.2016.04.012, 2016.

Lee, J.-S. M.: How to use Twitter to further your research career, Nature, https://doi.org/10.1038/d41586-019-00535-w, 2019.

Lemoine, A., Bertil, D., Roullé, A., and Briole, P.: The volcanotectonic crisis of 2018 east of Mayotte, Comoros islands, EarthArXiv, 55 pp., https://doi.org/10.31223/osf.io/d46xj, 2019.

Lomax, A., Bossu, R., and Mazet-Roux, G.: Real-Time Science on Social Media: The Example of Twitter in the Minutes, Hours, Days after the $2015 M_{7.8}$ Nepal Earthquake, in 2015 AGU Fall Meeting, AGU, available at: https://agu.confex.com/agu/fm15/ meetingapp.cgi/Paper/77222 (last access: 7 October 2019), 2015.

Morin, H.: Indonésie: polémique “ vaine " sur le système d'alerte tsunami, Le Monde, 1 October, available at: https://www.lemonde.fr/sciences/article/2018/10/01/ indonesie-polemique-vaine-sur-le-systeme-d-alerte-tsunami_ 5362931_1650684.html (last access: 5 September 2019), 2018.

Patton, J. R.: EarthquakeReport Italy, Twitter, available at: https: //twitter.com/patton_cascadia/status/792868409734291457 (last access: 8 October 2019), 2016.

Patton, J. R.: EarthquakeReport offshore of Madagascar, the Comoros Archipelago, Mayotte, Twitter, available at: https://twitter. com/patton_cascadia/status/996465298680115200 (last access: 8 October 2019), 2018.

Pusat Studi Gempa Nasional: National Center for Earthquake Studies: Peta Sumber dan Bahaya Gempa Indonesia Tahun 2017 Pusat Litbang Perumahan dan Pemukiman, Bandung, Indonesia, available at: http://geotek.lipi.go.id/wp-content/uploads/2018/ 02/BUKU-PETA-GEMPA-2017.pdf (last access: 20 October 2019), 2017.

Sample, I.: "Magma shift" may have caused mysterious seismic wave event, The Guardian, 30 November, available at: http://www.theguardian.com/science/2018/nov/30/ magma-shift-mysterious-seismic-wave-event-mayotte (last access: 15 July 2019), 2018.

Shi, X., Wang, Y., Liu-Zeng, J., Weldon, R., Wei, S., Wang, T., and Sieh, K.: How complex is the $2016 M_{\mathrm{w}} 7.8$ Kaikoura earthquake, South Island, New Zealand?, Sci Bull. Fac. Agric. Kyushu Univ., 62, 309-311, https://doi.org/10.1016/j.scib.2017.01.033, 2017.

Shiffman, S. D.: The Benefits of Twitter for Scientists, American Scientist, available at: https://www.americanscientist.org/blog/ macroscope/the-benefits-of-twitter-for-scientists (last access: 29 August 2019), 2017.

Socquet, A., Simons, W., Vigny, C., McCaffrey, R., Subarya, C., Sarsito, D., Ambrosius, B., and Spakman, W.: Microblock rotations and fault coupling in SE Asia triple junction (Sulawesi, Indonesia) from GPS and earthquake slip vector data, J. Geophys. Res., 111, B08409, https://doi.org/10.1029/2005jb003963, 2006.

Socquet, A., Hollingsworth, J., Pathier, E., and Bouchon, M.: Evidence of supershear during the 2018 magnitude 7.5 Palu 
earthquake from space geodesy, Nat. Geosci., 12, 192-199, https://doi.org/10.1038/s41561-018-0296-0, 2019.

Steed, R. J., Fuenzalida, A., Bossu, R., Bondár, I., Heinloo, A., Dupont, A., Saul, J., and Strollo, A.: Crowdsourcing triggers rapid, reliable earthquake locations, Sci. Adv., 5, eaau9824, https://doi.org/10.1126/sciadv.aau9824, 2019.

Stewart, I. S., Ickert, J., and Lacassin, R.: Communicating Seismic Risk: the Geoethical Challenges of a PeopleCentred, Participatory Approach, Ann. Geophys., 60, 17 pp., https://doi.org/10.4401/ag-7593, 2018.

Takahashi, B., Tandoc Jr., E. C., and Carmichael, C.: Communicating on Twitter during a disaster: An analysis of tweets during Typhoon Haiyan in the Philippines, Comput. Human Behav., 50, 392-398, https://doi.org/10.1016/j.chb.2015.04.020, 2015.

Ulrich, T., Vater, S., Madden, E. H., Behrens, J., van Dinther, Y., van Zelst, I., Fielding, E. J., Liang, C., and Gabriel, A.A.: Coupled, Physics-Based Modeling Reveals Earthquake Displacements are Critical to the 2018 Palu, Sulawesi Tsunami, Pure Appl. Geophys., 81, 5679, https://doi.org/10.1007/s00024-01902290-5, 2019.

Valkaniotis, S., Ganas, A., Tsironi, V., and Barberopoulou, A.: A preliminary report on the $M_{7.5}$ Palu 2018 earthquake co-seismic ruptures and landslides using image correlation techniques on optical satellite data, Zenodo, https://doi.org/10.5281/zenodo.1467128, 2018.

Van Noorden, R.: Online collaboration: Scientists and the social network, Nature, 512, 126-129, https://doi.org/10.1038/512126a, 2014.
Watkinson, I. M. and Hall, R.: Fault systems of the eastern Indonesian triple junction: evaluation of Quaternary activity and implications for seismic hazards, Geol. Soc. Lond. Spec. Publ., 441, 71-120, https://doi.org/10.1144/sp441.8, 2017.

Watkinson, I. M. and Hall, R.: Impact of communal irrigation on the 2018 Palu earthquake-triggered landslides, Nat. Geosci., 12, 940-945, https://doi.org/10.1038/s41561-019-0448-x, 2019.

Wei-Haas, M.: The Science of Indonesia's Surprise Tsunami, National Geographic, 1 October, available at: https://www.nationalgeographic.com/environment/2018/09/ indonesia-tsunami-sulawesi-explained-science-geology/ (last access: 5 July 2019), 2018a.

Wei-Haas, M.: Strange waves rippled around the world, and nobody knows why, National Geographic, 28 November, available at: https://www.nationalgeographic.com/science/2018/11/ strange-earthquake-waves-rippled-around-world-earth-geology/ (last access: 5 July 2019), 2018b.

Williams, R. and Krippner, J.: The use of social media in volcano science communication: challenges and opportunities, Volcanica, 1, i-viii, https://doi.org/10.30909/vol.01.02.i-viii, 2019.

Wright, S.: Warning system might have saved lives in Indonesian tsunami, Associated Press, 1 October, available at: https:// apnews.com/110eb42c03324a08bff5b3e6b58c309e (last access: 5 September 2019), 2018.

Zakaria, N., Amelinckx, A., and Wilemon, D.: Working Together Apart? Building a Knowledge-Sharing Culture for Global Virtual Teams, Creat. Innov. Manag., 13, 15-29, https://doi.org/10.1111/j.1467-8691.2004.00290.x, 2004. 